\title{
Gamma- $\mathrm{C}_{2} \mathrm{~S}$ Synthesis from Fly Ash of Fluidize-Bed Boiler for $\mathrm{CO}_{2}$ Capture
}

\author{
$\mathrm{S} . \mathrm{NA}^{a}, \mathrm{~S} \cdot \mathrm{KANG}^{b}, \mathrm{~S} . \mathrm{LEE}^{b}, \mathrm{M} . \mathrm{SONG}^{a, *}$ \\ ${ }^{a}$ Research Center of Advanced Convergence Processing on Materials, \\ Kangwon National University, Samcheok, Republic of Korea \\ ${ }^{b}$ Dept. of Advanced Materials Engineering, Kangwon \\ National University, Samcheok, Republic of Korea
}

\begin{abstract}
This paper describes the $\mathrm{CO}_{2}$ capture performance of cement blended paste incorporating gamma-dicalcium silicate (gamma- $\mathrm{C}_{2} \mathrm{~S}$ ) made with industrial by-products, by taking into consideration of effect of $\mathrm{CaCO}_{3}$, fly ash replacement ratio under the sintering process. X-ray diffraction method was conducted in order to quantitatively investigate the gamma- $\mathrm{C}_{2} \mathrm{~S}$ content. $\mathrm{CO}_{2}$ capture performance of mortar sample incorporating gamma- $\mathrm{C}_{2} \mathrm{~S}$ was investigated by means of compressive strength test using accelerated carbonation chamber. The experimental results revealed that the kind of $\mathrm{CaCO}_{3}$ would affect the affect the formation of gamma- $\mathrm{C}_{2} \mathrm{~S}$ after the sintering with respect to the XRD-Rietveld analysis. Moreover, it is confirmed that compressive strength of mortar sample incorporating gamma- $\mathrm{C}_{2} \mathrm{~S}$ has the same tendency at curing age of 3, 7 and 28days. Blended mortar sample made with 10 wt.\% replacement ratio of gamma- $\mathrm{C}_{2} \mathrm{~S}$ had high compressive strength value compared to normal mortar sample, therefore, incorporating gamma- $\mathrm{C}_{2} \mathrm{~S}$ had a positive effect on the compressive strength after accelerated carbonation. Finally, the waste foundry sand powder may be alternative to produce gamma- ${ }_{2} \mathrm{~S}$.
\end{abstract}

DOI: 10.12693/APhysPolA.127.1282

PACS: $81.05-\mathrm{t}$

\section{Introduction}

Concrete, which consists of water, cement, fine and coarse aggregates, has been widely used for a long time in the civil engineering and construction field all over the world, as many benefits such as low cost, extremely strong compression and so on. However, although there are many advantages, there are some disadvantages that the use of high cement contents in the manufacturing cement product can occur the high amounts of $\mathrm{CO}_{2}$, leading to the atmospheric environmental pollution. One of the few ways of reducing $\mathrm{CO}_{2}$ emission migration are that admixtures such as fly ash, blast furnace slag as partial replacement of Portland cement use in the cement blended systems [1]. Another approaches to the reducing atmospheric environmental pollution are $\mathrm{CO}_{2}$ capture and storage technology in cementitious composite incorporating gamma-dicalcium silicate, which called Gamma$\mathrm{C}_{2} \mathrm{~S}$ [2]. Gamma- $\mathrm{C}_{2} \mathrm{~S}$, which provides non-hydraulic materials, is a promising material for reducing $\mathrm{CO}_{2}$ emission. There are many studies in the literatures that have dealt with gamma- $\mathrm{C}_{2} \mathrm{~S}$ from $\mathrm{CaCO}_{3}$ and $\mathrm{CaO}$, and sand [3-5]. However, the development of gamma- $\mathrm{C}_{2} \mathrm{~S}$ incorporating industrial by-product like waste foundry sand powder was limited. The waste foundry sand powder has high $\mathrm{SiO}_{2}$ contents, thus, it may be alternative regarding gamma- $\mathrm{C}_{2} \mathrm{~S}$ manufacturing. The main objective is to investigate the $\mathrm{CO}_{2}$ capture performance of cement blended paste incorporating gamma- $\mathrm{C}_{2} \mathrm{~S}$. The experimental work in this study consists of two parts. The

*corresponding author; e-mail: msong0422@kangwon.ac.kr first part develops the gamma- $\mathrm{C}_{2} \mathrm{~S}$ contents of clinker made with different waste $\mathrm{CaCO}_{3}$, waste foundry sand and fly ash of fluidize-bed boiler under the sintering process. The second part concerns with $\mathrm{CO}_{2}$ capture performance of the cement blended mortar sample incorporating synthesized gamma- $\mathrm{C}_{2} \mathrm{~S}$ with respect to compressive strength before and after accelerated carbonation curing. Details of the experimental plan and investigated gamma- $\mathrm{C}_{2} \mathrm{~S}$ blended cement samples are given below.

\section{Experimental}

The experimental work in this study consists of two parts. The first part deals with gamma- $\mathrm{C}_{2} \mathrm{~S}$ product made with waste $\mathrm{CaCO}_{3}$ and waste foundry sand powder after the sintering. The second part concerns with $\mathrm{CO}_{2}$ capture performance of the mortar sample incorporating the synthesized gamma- $\mathrm{C}_{2} \mathrm{~S}$ with respect to the carbonation test, considering the gamma- $\mathrm{C}_{2} \mathrm{~S}$ replacement ratio and curing age. Synthesized gamma- $\mathrm{C}_{2} \mathrm{~S}$ were confirmed by the X-ray diffraction Rietvelt method. And compressive strength were investigated to identify the effect of gamma- $\mathrm{C}_{2} \mathrm{~S}$ on $\mathrm{CO}_{2}$ capture behavior. Details of the experimental plan and investigated gamma- $\mathrm{C}_{2} \mathrm{~S}$ blended cement samples are given below.

\subsection{Raw materials used}

The physical properties and chemical composition of ordinary Portland cement (OPC), two types of $\mathrm{CaCO}_{3}$, waste foundry sand (WFS) powder and fluidize-bed boiler fly ash are shown in Table I and II. The waste $\mathrm{CaCO}_{3}$ with Yongyun $\left(\mathrm{Y}-\mathrm{CaCO}_{3}\right)$, Dogae $\left(\mathrm{D}-\mathrm{CaCO}_{3}\right)$ and waste foundry sand powder were used to create gamma- $\mathrm{C}_{2} \mathrm{~S}$. As shown in the Fig. 1, fly ash of fluidizebed boiler that industrial by-products material were consist of $\mathrm{CaO}$ and $\mathrm{CaSO}_{4}$. 


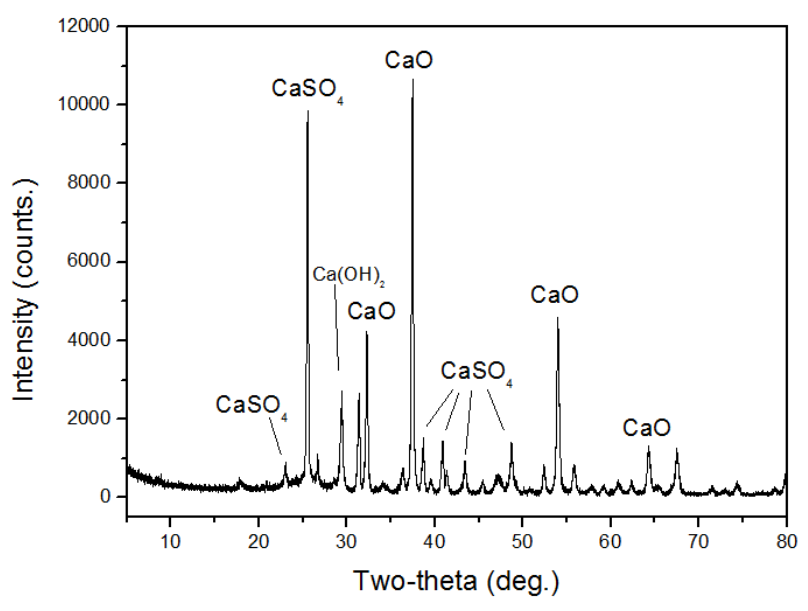

Fig. 1. X-ray diffraction patterns of fly ash.

Physical and chemical properties of OPC.

TABLE I

\begin{tabular}{c|c|c|c|c|c|c|c|c|c}
\hline \hline $\mathrm{SiO}_{2}$ & $\mathrm{Al}_{2} \mathrm{O}_{3}$ & $\mathrm{CaO}$ & $\mathrm{MgO}$ & $\mathrm{Fe}_{2} \mathrm{O}_{3}$ & $\mathrm{Na}_{2} \mathrm{O}$ & $\mathrm{K}_{2} \mathrm{O}$ & $\mathrm{SO}_{3}$ & $\begin{array}{c}\text { Specific } \\
\text { gravity }\end{array}$ & $\begin{array}{c}\text { Blaine } \\
{\left[\mathrm{cm}^{2} / \mathrm{g}\right]}\end{array}$ \\
\hline 17.30 & 4.08 & 66.50 & 3.02 & 3.13 & 0.09 & 1.33 & 3.25 & 3.15 & 3.412
\end{tabular}

\subsection{Sintering process}

Two types of $\mathrm{CaCO}_{3}$ was used to investigate the effect of $\mathrm{CaCO}_{3}$ on the gamma- $\mathrm{C}_{2} \mathrm{~S}$ content after sintering, the mix proportion with 5:1 (by weight) of $\mathrm{CaCO}_{3}$ and waste foundry sand powder was designed [6]. The raw materials were dried at $105{ }^{\circ} \mathrm{C}$ for $24 \mathrm{hrs}$ and then milled less than $75 \mu \mathrm{m}$ before sintering. They were mixed with ball mill for $60 \mathrm{~min}$ and pressed at $20 \mathrm{MPa}$. After pressed, the obtained clinker was exposed to sintering temperature $\left(10{ }^{\circ} \mathrm{C} / \mathrm{min}\right)$ at $900{ }^{\circ} \mathrm{C}$ for $30 \mathrm{~min}$ and they were subjected to $1450{ }^{\circ} \mathrm{C}$ for 30 min using electric furnace. Then, the sintered clinker was cooled in room temperature. The produced materials were milled using ball mill at $400 \mathrm{rpm}$ for $1 \mathrm{~min}$, and sieved less than $106 \mu \mathrm{m}$.

\subsection{Preparation of samples and testing methods}

After sintering, XRD-Rietveld analysis (Rigaku Ultima II diffractometer, Japan) was performed in order to confirm gamma- $\mathrm{C}_{2} \mathrm{~S}$ content in the clinker. In mortar experiment, water to cement ratio $(\mathrm{W} / \mathrm{C})$ and cement and sand $(\mathrm{C} / \mathrm{S})$ were 0.5 and 1:3. Gamma- $\mathrm{C}_{2} \mathrm{~S}$ content replacement ratios were 0, 5 and 10 wt.\% by cement. Each material was mixed 2 minutes using a mortar mixer and then casted in prism with dimension of $40 \times 40 \times 160 \mathrm{~mm}^{3}$ for 1 day. After casting, they were cured at $40{ }^{\circ} \mathrm{C}$ for 3 days as accelerated high temperature curing to evaporate the water within the mortar sample, because the relative humidity can affect the $\mathrm{CO}_{2}$ carbonation. Then

Chemical and physical characteristics of TABLE II raw materials.

\begin{tabular}{c|c|c|c|c|c|c|c|c|c|c|c}
\hline \hline & $\mathrm{CaO}$ & $\mathrm{CO}_{2}$ & $\mathrm{SiO}_{2}$ & $\mathrm{Al}_{2} \mathrm{O}_{3}$ & $\mathrm{MgO}$ & $\mathrm{K}_{2} \mathrm{O}$ & $\mathrm{Fe}_{2} \mathrm{O}_{3}$ & $\mathrm{SO}_{3}$ & $\mathrm{~B}_{2} \mathrm{O}_{3}$ & $\mathrm{Other}$ & $\mathrm{LOI}$ \\
\hline${\mathrm{Y}-\mathrm{CaCO}_{3}}^{51.80}$ & 41.10 & 3.28 & 2.09 & 0.50 & 0.48 & 0.40 & 0.0285 & - & 0.32 & 41.10 \\
$\mathrm{D}-\mathrm{CaCO}_{3}$ & 51.80 & 43.60 & 0.68 & 0.34 & 2.98 & 0.09 & 0.37 & 0.0366 & - & 0.10 & 43.60 \\
WFS & 0.13 & - & 97.00 & 1.83 & 0.05 & 0.34 & - & - & - & 0.65 & - \\
$\mathrm{Fly} \mathrm{ash}$ & 65.61 & - & 1.15 & 0.56 & 2.57 & - & 0.62 & 21.48 & 2.14 & 5.87 & -
\end{tabular}

their samples were sealed using a plastic bag at $20{ }^{\circ} \mathrm{C}$ for 28 days. The compressive strength of the cured mortar samples at curing age of 3,7 and 28 days was tested by means of universal testing machine (UTM). This is no carbonation case.

In carbonation case, casted mortar samples after 3 days were moved into carbonation chamber at condition of $10 \%$ of $\mathrm{CO}_{2}$ concentration, $20{ }^{\circ} \mathrm{C}$ and $60 \%$ RH. After curing age of 28 and 56 days, compressive strength test of all investigated mortar samples after carbonation was conducted by UTM to investigate the effect of gamma$\mathrm{C}_{2} \mathrm{~S}$ on carbonation. Three samples were tested and their average values were reported.

\section{Results and discussion}

\subsection{Synthesized gamma- $C_{2} S$ contents with different types of $\mathrm{CaCO}_{3}$}

The gamma polymorph of dicalcium silicate $\left(\mathrm{C}_{2} \mathrm{~S}\right)$ forms at temperatures about $550{ }^{\circ} \mathrm{C}$ through the beta to gamma conversion. This conversion involves a rotation of the $\mathrm{SiO}_{4}$ tetrahedral and large movements of calcium atoms with an accompanied volume increase of $12 \%$ causing a break up into small particles, a phenomenon known as "dusting", as shown in Fig. 2. X-ray diffraction patterns of XRD analysis of the sintered clinker made with $\mathrm{D}-\mathrm{CaCO}_{3}, \mathrm{Y}-\mathrm{CaCO}_{3}$ and WFS powder represents in Fig. 3. From the figure, in the case of peak intensity of gamma- $\mathrm{C}_{2} \mathrm{~S}$ in the sample incorporating $\mathrm{D}-\mathrm{CaCO}_{3}$ sample was higher than that of $\mathrm{Y}-\mathrm{CaCO}_{3}$ sample after the sintering. To quantitatively evaluate the gamma$\mathrm{C}_{2} \mathrm{~S}$ contents of the sample after sintering, XRD-Rietveld analysis was performed. From the observation above, the types of $\mathrm{CaCO}_{3}$ can affect the Gamma- $\mathrm{C}_{2} \mathrm{~S}$ contents with respect to the XRD-Rietveld analysis, therefore, the Y$\mathrm{CaCO}_{3}$ sample was chosen in order to avoid the decrease of gamma- $\mathrm{C}_{2} \mathrm{~S}$ contents after sintering.

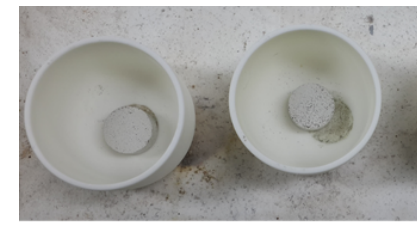

(a) Before sintering

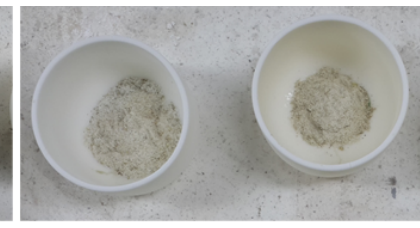

(b) After sintering
Fig. 2. Phenomenon of dusting.

\subsection{Effects of retention time and fly ash replacement ratio on the gamma- $C_{2} S$}

The results of the XRD-Rietveld analysis of clinker with fly ash replacement ratios varies as $0,0.5,1.0,3.0$ and 5.0 wt.\% are given in Table III and Fig. 4. Retention time of clinker in the sintering process was $30 \mathrm{~min}$. It is found from the figure that when the fly ash replacement ratios increase from 0 to $5.0 \mathrm{wt} . \%$, the contents of gamma- $\mathrm{C}_{2} \mathrm{~S}$ decrease with increasing the fly ash replacement ratio after sintering, suggesting that addition the fly ash was found to have negative effect on the 


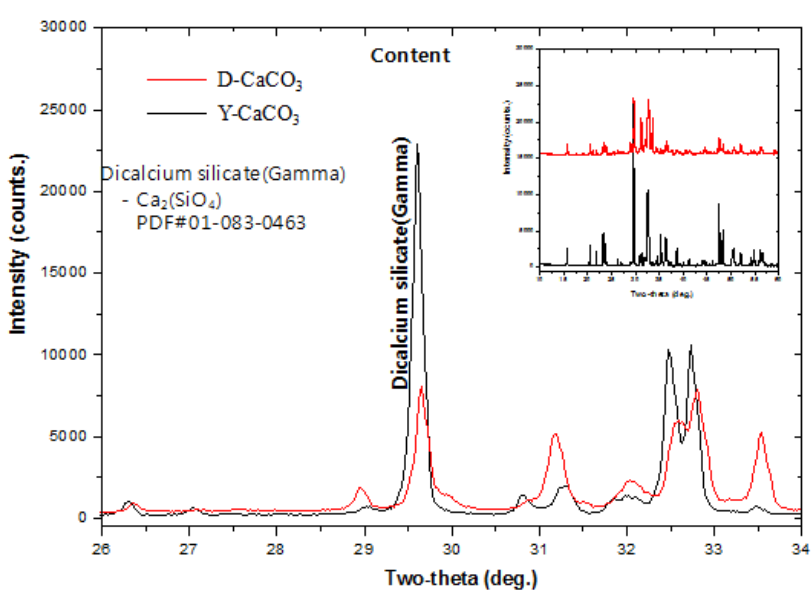

Fig. 3. X-ray diffraction patterns of XRD analysis of calcined powder made with $\mathrm{CaCO}_{3}$ and waste foundry sand powder.

clinker sintered with respect to the XRD-Rietveld analysis. In addition, there is no clear explanation for this phenomenon. A possible hypothesis is due the fact that the fly ash would have an impurity contents and $\mathrm{B}_{2} \mathrm{O}_{3}$ content. Therefore, the gamma- $\mathrm{C}_{2} \mathrm{~S}$ content seemed to be governed by the impurity contents and present of $\mathrm{B}_{2} \mathrm{O}_{3}$. According to previous studies, beta- $\mathrm{C}_{2} \mathrm{~S}$ to gamma- $\mathrm{C}_{2} \mathrm{~S}$ conversion can be suppressed by rapid cooling and/or by addition of suitable impurity ions such as boron [7].

Relationship between gamma- $\mathrm{C}_{2} \mathrm{~S}$ content and retention time presents in Fig. 5. It is confirmed that contents of gamma- $\mathrm{C}_{2} \mathrm{~S}$ increase with increasing the retention time, and contents of gamma- $\mathrm{C}_{2} \mathrm{~S}$ for 30 and $60 \mathrm{~min}$ were $60.6 \%$ and $80.5 \%$ due to the fact that long retention time causes heat of retention time.

The result of the XRD-Rietveld analysis of clinker sintered with fly ash replacement ratios clinker with $3 \mathrm{wt} . \%$ of fly ash replacement ratio as shown in Fig. 5 .

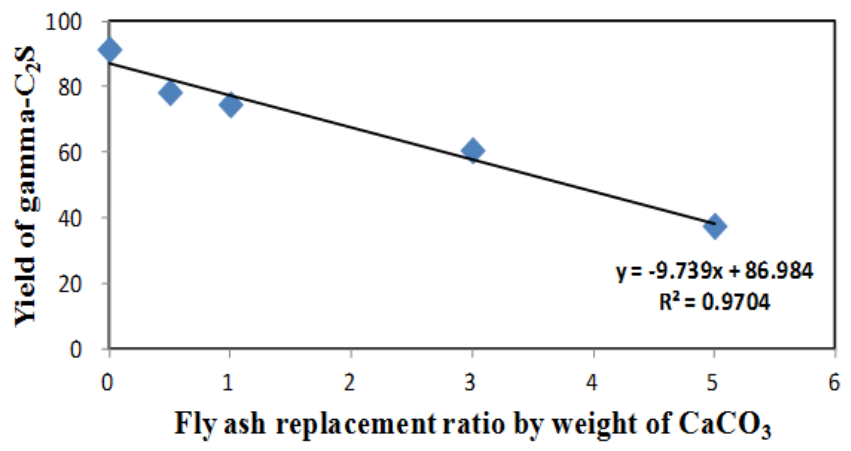

Fig. 4. Yield of gamma- $\mathrm{C}_{2} \mathrm{~S}$ by fly ash replacement ratio.
Contents of gamma- $\mathrm{C}_{2} \mathrm{~S}$ with different fly ash replacement ratio by means of XRDRietvelt analysis.

\begin{tabular}{c|c|c|c|c|c}
\hline \hline \multirow{2}{*}{ Profile ID } & \multicolumn{5}{|c}{ Fly ash replacement ratio } \\
& \multicolumn{5}{|c}{ by weight of $\mathrm{CaCO}_{3}$} \\
\cline { 2 - 6 } & $0 \%$ & $0.5 \%$ & $1.0 \%$ & $3.0 \%$ & $5.0 \%$ \\
\hline $\begin{array}{c}\text { Dicalcium silicate } \\
\mathrm{Ca}_{2}\left(\mathrm{SiO}_{4}\right)\end{array}$ & 91.4 & 78.3 & 74.6 & 60.6 & 37.5 \\
\hline $\begin{array}{c}\text { Calcium silicate } \\
\mathrm{Ca}_{2} \mathrm{SiO}_{4}\end{array}$ & - & 0.3 & 1.2 & 1.6 & 1.3 \\
\hline $\begin{array}{c}\mathrm{Calcium} \mathrm{silicate} \\
\mathrm{Ca}\left(\mathrm{SiO}_{3}\right)\end{array}$ & - & - & - & - & - \\
\hline $\mathrm{Lime}-\mathrm{CaO}_{\mathrm{L}}$ & - & 11.4 & 9.3 & 11.9 & 16.0 \\
\hline $\begin{array}{c}\mathrm{Larnite} \\
\mathrm{Ca}\end{array} \mathrm{SiO}_{4}$ & - & - & 7.7 & 19.0 & 38.6 \\
\hline $\begin{array}{c}\mathrm{Akermanite} \\
\left.\mathrm{Ca}_{2} \mathrm{Mg}_{(\mathrm{Si}} \mathrm{O}_{7}\right)\end{array}$ & 8.6 & - & - & - & - \\
\hline $\begin{array}{c}\mathrm{Hatrurite} \\
\mathrm{Ca}_{3} \mathrm{SiO}_{5}\end{array}$ & - & 10.0 & 7.2 & 6.9 & 6.6 \\
\hline Total & 100.0 & 100.0 & 100.0 & 100.0 & 100.0
\end{tabular}

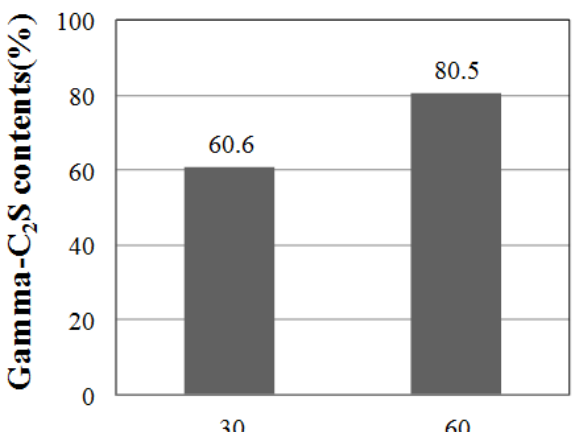

Retention time (min)

Fig. 5. Relationship between gamma- $\mathrm{C}_{2} \mathrm{~S}$ content and retention time.

\subsection{Change of compressive strength before and after $\mathrm{CO}_{2}$ Exposure}

Figure 6 shows the result of compressive strength for gamma- $\mathrm{C}_{2} \mathrm{~S}$ blended cement mortar samples with gamma- $\mathrm{C}_{2} \mathrm{~S}$ replacement ratio of 0,5 and $10 \%$ by weight at curing age of 3,7 and 28 days. This case was no acceleration carbonation case. From the figure, in comparison to normal mortar sample with 0 wt.\% gamma- $\mathrm{C}_{2} \mathrm{~S}$, the compressive strength of mortar samples with 5 and 10 wt.\% of gamma- $\mathrm{C}_{2} \mathrm{~S}$ replacement ratio appeared to have the same tendency, implying that incorporating the gamma- $\mathrm{C}_{2} \mathrm{~S}$ did not affect the compressive strength in the investigated mortar samples.

Figure 7 shows the result of compressive strength for gamma- $\mathrm{C}_{2} \mathrm{~S}$ blended cement mortar samples after accelerated carbonation curing at $10 \%$ of $\mathrm{CO}_{2}$ concentration, $20{ }^{\circ} \mathrm{C}$ and $60 \% \mathrm{RH}$. In this case, the mortar samples after 28 days were tested. After carbonation, it can be seen from the figures the investigated sample with $10 \mathrm{wt} . \%$ 


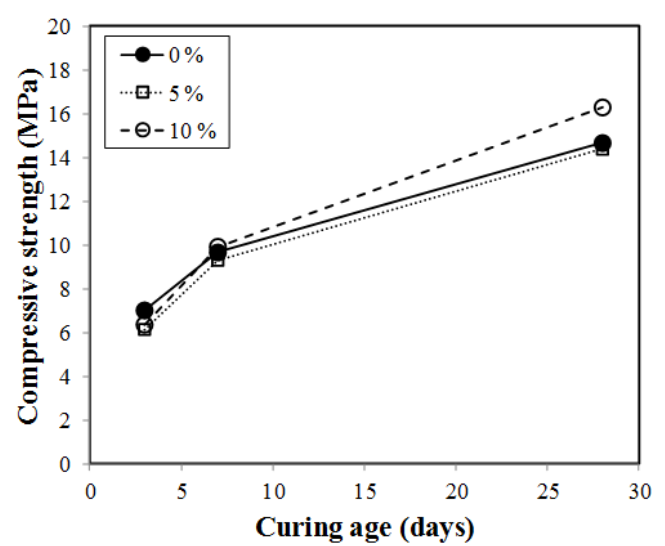

Fig. 6. Change of compressive strength with investigated mortar sample before carbonation.

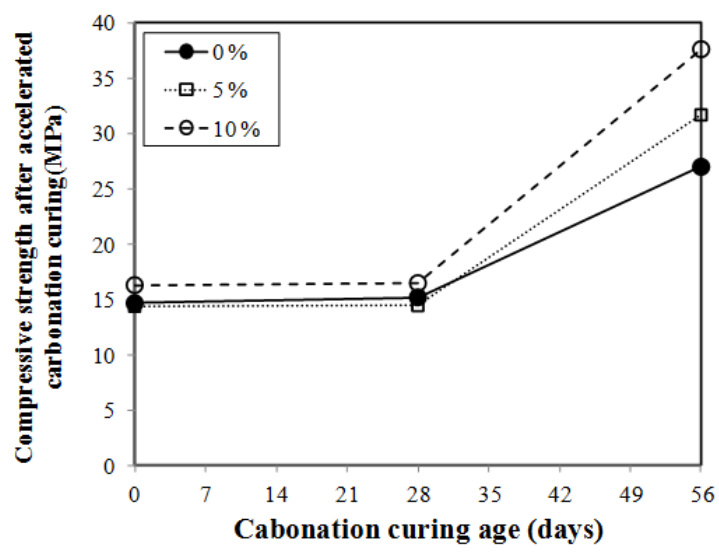

Fig. 7. Change of compressive strength with investigated mortar sample after carbonation.

of gamma- $\mathrm{C}_{2} \mathrm{~S}$ replacement ratio can increase the compressive strength in comparison to control mortar sample ( $0 \%$ of the gamma- $\mathrm{C}_{2} \mathrm{~S}$ replacement ratio). The reason for this behavior is because the gamma- $\mathrm{C}_{2} \mathrm{~S}$ that reacts with $\mathrm{CO}_{2}$ and then produces $\mathrm{CaCO}_{3}$ phase, therefore, densification of cement matrix occurs, resulting in the increase of compressive strength [3].

\section{Conclusion}

In this study, the effects of raw materials with different waste $\mathrm{CaCO}_{3}$, waste foundry sand and fly ash of fluidize-bed boiler on gamma- $\mathrm{C}_{2} \mathrm{~S}$ development were investigated by means of XRD-Rietveld analysis and compressive strength under accelerated carbonation curing. It was found that gamma- $\mathrm{C}_{2} \mathrm{~S}$ content under the sintering process depends on the types of $\mathrm{CaCO}_{3}$, high gamma$\mathrm{C}_{2} \mathrm{~S}$ contents were obtained from $\mathrm{D}-\mathrm{CaCO}_{3}$ with waste foundry sand. As the retention time increases for 30 and $60 \mathrm{~min}$, gamma- $\mathrm{C}_{2} \mathrm{~S}$ contents would increase due to the heat of formation in the clinker under the sintering process. After carbonation, compressive strength of blended sample made with 10 wt.\% replacement ratio of gamma$\mathrm{C}_{2} \mathrm{~S}$ would increase in comparison to the normal mortar sample. This finding would be due to the reason that the gamma- $\mathrm{C}_{2} \mathrm{~S}$ reacts with $\mathrm{CO}_{2}$ and then produces $\mathrm{CaCO}_{3}$ phase, leading to the densification of cement matrix.

\section{References}

[1] I. Yoshioka, D. Obataa, H. Nanjoa, K. Yokozekib, T. Torichigaib, M. Moriokac, T. Higuchic, Energy Procedia 37, 6018 (2013).

[2] L. Kriskova, Y. Pontikes, F. Zhang, Ö. Cizer, P.T. Jones, K.V. Balen, B. Blanpain, Cement and Concrete Research 55, 59 (2014).

[3] K. Watanabe, K. Yokozeki, R. Ashizawa, N. Sakata, M. Morioka, E. Sakai, M. Daimon, Waste Management 26, 752 (2006).

[4] M. Lesti, C. Tiemeyer, J. Plank, Cement and Concrete Research 45, 45 (2013).

[5] M. Dova, M. Palou, V. Kovar, Ceramics-Silikáty 50, 106 (2006).

[6] S.H. Lee, S.M. Kang, S.H. Na, M.S. Song, Y.I. Woo, The Proceedings of 41th Cement Symposium, 91 (2014).

[7] L. Kriskova, Y. Pontikes, L. Pandelaers, Ö. Cizer, P.T. Jones, K. Van Balen, B. Blanpain, Metallurgical and Materials Transactions B, 1 (2013). 